American Journal of Applied Sciences 8 (11): 1073-1080, 2011

ISSN 1546-9239

(C) 2011 Science Publications

\title{
Growth Enhancement and Disease Reduction of Soybean by 1-Aminocyclopropane-1-Carboxylate Deaminase-Producing Pseudomonas
}

\author{
${ }^{1}$ Edi Husen, ${ }^{1}$ Aris Tri Wahyudi, ${ }^{1}$ Antonius Suwanto and ${ }^{2}$ Giyanto \\ ${ }^{1}$ Department of Biology, Faculty of Mathematics and Natural Sciences \\ ${ }^{2}$ Department of Plant Protections, Faculty of Agriculture, \\ Bogor Agricultural University (IPB), Jl. Agatis, Kampus IPB Dramaga \\ Bogor 16680, Indonesia
}

\begin{abstract}
Problem statement: 1-Aminocyclopropane-1-Carboxylate (ACC) deaminase-producing bacteria have been known to ameliorate the inhibition-effect of increase concentration of ethylene in higher plants, which can be triggered by high concentration of indole-3-Acetic Acid (IAA) and/or by the presence of plant pathogens. This study examined the potential use of Pseudomonas isolates producing ACC deaminase as well as IAA to enhance soybean growth and reduce disease incidence in soil containing pathogenic fungi. Approach: Eleven promising ACC deaminase-producing isolates of Pseudomonas were retested in vitro for their ACC deaminase activity and IAA production and evaluated their potential antagonist against root-nodule bacteria. Non antagonist isolates were further tested for their ability to enhance soybean growth and reduce disease incidence in sterile and non-sterile soils containing root-pathogenic fungi Fusarium oxysporum, Sclerotium rolfsii and Rhizoctonia solani. Results: All isolates produced ACC deaminase as well as IAA, but 3 out of 11 isolates inhibited at least one strain of rhizobia which limit their use for soybean. The isolates increased some aspects of soybean growth, but most of the increases were not significantly different from untreated control. Most isolates significantly increased the survival rates of soybean in soil containing pathogenic fungi although their ability to reduce plant weight loss varied across pathogen treatments. Conclusion: The ability of Pseudomonas producing ACC deaminase as well as IAA to increase plant growth was less significant than that of the isolates to reduce disease incidence. The higher the destructive effect of the pathogens, the better was the ability of the isolates to reduce the disease.
\end{abstract}

Key words: ACC deaminase, disease incidence, Fusarium oxysporum, growth enhancement, IAA, Pseudomonas, Rhizoctonia solani, Sclerotium rolfsii, soybean

\section{INTRODUCTION}

A number of 1-Aminocyclopropane-1-Carboxylate (ACC) deaminase-producing bacteria have been known to help plant growth by ameliorating the negative effects of increased concentration of ethylene in higher plants. As a senescing hormone (Abeles et al., 1992; Arshad and Frankenberger, 1991), increased concentration of ethylene after seed germination inhibits root development (Glick, 1995; Shah et al., 1998) and nodulation of various legumes (Ma et al., 2003). Regarding plant-pathogen interactions, ethylene produced during plant infection promotes disease rather than alleviating it (Van Loon et al., 2006). Ample studies on the benefits of ACC deaminase-producing bacteria in reducing ethylene synthesis caused by various biotic and abiotic stresses have been reported, such as those caused by high concentration of IAA (Mayak et al., 1999), water logging (Grichko and Glick, 2001), nutritional stress (Belimov et al., 2002), drought (Mayak et al., 2004), organic and inorganic pollutants (Reed and Glick, 2005; Belimov et al. 2001), high salts (Saravanakumar and Samiyappan, 2007) and pathogenic infection (Wang et al., 2000; Dey et al., 2004; Shaharoona et al., 2006). Thus, applying ACC deaminase producing bacteria to reduce ethylene synthesis in the plant, whenever it starts accelerating may become one of the promising strategies to increase plant growth and prevent disease development.

Corresponding Author: Aris Tri Wahyudi, Department of Biology, Faculty of Mathematics and Natural Sciences (MIPA), Bogor Agricultural University (IPB), Bogor 16680, Indonesia Tel/Fax: +62-251-8622833 
Our previous experiments on the promoting effects of Pseudomonas producing Indole-3-Acetic Acid (IAA) on soybean seedlings were also related to their ACC deaminase activities. Their ACC deaminase activities optimized the promoting effects of IAA and increased root elongation and shoot weight of soybean seedlings (Husen et al., 2009). It suggests that the bacteria may have the capacity to reduce disease development as described by previous reports (Wang et al., 2000; Glick et al., 2007). However, since the effectiveness of the bacteria may vary depending on the nutrient status of the media (Shaharoona et al., 2006; 2007) and the fitness of the bacteria with host plants (Silvia, 2005), these abilities are worth to be verified.

The objective of the present study was to examine the ability of Pseudomonas producing ACC deaminase as well as IAA to enhance soybean growth and reduce disease development in potted soil containing pathogenic fungi.

\section{MATERIALS AND METHODS}

Bacterial isolates, pathogenic fungi and growth media: Eleven isolates of plant growth promotingPseudomonas, designated as Crb5, Crb12, Crb17, Crb24, Crb26, Crb46, Crb47, Crb49, Crb53, Crb56 and Crb94 were used in the study. The origin of the bacteria was from the rhizosphere of soybean grown in Plumbon agricultural area in Cirebon, West Java, Indonesia. The bacteria were selected from 81 indole-3-acetic acidproducing Pseudomonas as well as 1Aminocyclopropane-1-Carboxylate (ACC) deaminase (E.C.4.1.99.4) and significantly promoted soybean seedlings under growth chamber conditions (Husen et $a l ., 2009)$. Two rhizobial strains for inhibition tests, i.e., Bradyrhizobium japonicum Bj11 and Sinorhizobium fredii Rif5 and three known phytopathogenic fungi for disease reduction tests, i.e., Fusarium oxysporum, Sclerotium rolfsii and Rhizoctonia solani were obtained from the Laboratory of Soil Biology, Indonesian Soil Research Institute (ISRI); Laboratory of Microbiology, Department of Biology, Faculty of Mathematics and Natural Sciences, Bogor Agricultural University (IPB); and the culture collection of Department of Plant Protection, Faculty of Agriculture, IPB. Seeds of soybean (Glycine max L. Merr.) cv. Wilis were obtained from the Indonesian Center for Biotechnology and Genetics Resources Research and Development, Bogor.

Depending on the assay, each isolate from stock culture was grown in Dworkin-Foster (DF) Minimal Salts (MS) medium (Dworkin and Foster, 1958) supplemented with either ACC or ammonium sulfate to check the activity of ACC deaminase, MS tryptophan medium (Frankenberger and Poth, 1988) for IAA tests, King's B Medium (KBM) for antagonism tests and in M26 rich medium for bacterial cell production. The rhizobial strain was also grown in KBM for inhibition tests, while the pathogenic fungus was cultured and maintained in potato dextrose broth. The composition of DF MS medium was $4 \mathrm{~g} \mathrm{KH}_{2} \mathrm{PO}_{4}, 6 \mathrm{~g} \mathrm{Na}_{2} \mathrm{HPO}_{4}, 0.2$ g $\mathrm{MgSO}_{4} .7 \mathrm{H}_{2} \mathrm{O}, 1 \mathrm{mg} \mathrm{FeSO} \mathrm{m}_{4} .7 \mathrm{H}_{2} \mathrm{O}, 10 \mu \mathrm{g} \mathrm{H}_{3} \mathrm{BO}_{3}, 10$ $\mu \mathrm{g} \mathrm{MnSO}_{4}, 70 \mu \mathrm{g} \mathrm{ZnSO}_{4}, 50 \mu \mathrm{g} \mathrm{CuSO}_{4}, 10 \mu \mathrm{g} \mathrm{MoO}_{3}, 2$ $\mathrm{g}$ glucose, $2 \mathrm{~g}$ gluconic acid, $2 \mathrm{~g}$ citric acid, $1000 \mathrm{ml}$ distilled water+either $0.3033 \mathrm{~g} \mathrm{~L}^{-1}$ ACC or $2 \mathrm{~g} \mathrm{~L}^{-1}$ ammonium sulfate and solidified with $15 \mathrm{~g}$ agar. The MS-tryptophan medium was a mixture of $900 \mathrm{ml}$ MS medium and $100 \mathrm{ml}$ stock solution of L-tryptophan solidified with $15 \mathrm{~g}$ agar. The MS medium contained (in $900 \mathrm{ml}$ distilled water) $1.36 \mathrm{~g} \mathrm{KH}_{2} \mathrm{PO}_{4}, 2.13 \mathrm{~g}$ $\mathrm{Na}_{2} \mathrm{HPO}_{4}, 0.2 \mathrm{~g} \mathrm{MgSO}_{4} .7 \mathrm{H}_{2} \mathrm{O}$ and trace elements and stock solution of L-tryptophan contained (in $100 \mathrm{ml}$ distilled water) $10 \mathrm{~g}$ glucose, $1 \mathrm{~g}$ L-tryptophan and 0.1 $\mathrm{g}$ yeast extract. The $\mathrm{KBM}$ contained $20 \mathrm{~g}$ peptone, 10 $\mathrm{ml}$ glycerol, $1.5 \mathrm{~g} \mathrm{~K}_{2} \mathrm{HPO}_{4}, 1.5 \mathrm{~g} \mathrm{MgSO}_{4} .7 \mathrm{H}_{2} \mathrm{O}, 15 \mathrm{~g}$ agar (for solid media) and $1000 \mathrm{ml}$ distilled water. The M26 broth medium contained $10 \mathrm{~g}$ beef extract, $10 \mathrm{~g}$ proteose peptone, $5 \mathrm{~g} \mathrm{NaCl}$ and $1000 \mathrm{ml}$ distilled water. Unless otherwise noted, all media constituents were mixed and sterilized by autoclaving at $121^{\circ} \mathrm{C}$ for 15 min. The heat-labile ACC and stock solution of Ltryptophan was filtered-sterilized each by $0.2 \mu \mathrm{m}$ membrane filter before adding to the sterilized medium.

A bulk of the Ap horizon of Ultisols for pot experiments was obtained from upland agricultural area in Jasinga, Bogor. Prior to potting, the soil was prepared by passing through a 2-mm sieve and analyzed for soil texture, $\mathrm{pH}, \mathrm{C}$-organic and selected nutrients according to the standard procedures of the Soil Chemistry Laboratory of Indonesian Soil Research Institute (ISRI) in Bogor. Data on soil sample analyses in Table 1 showed that the soil is acidic with fine texture, low organic content and low fertility status.

In vitro tests: The ACC deaminase activity of each isolate was verified by growing in the DF salt minimal medium, supplemented with either ACC (DF-ACC) or ammonium sulfate (DF-Ammonium Sulfate) as described by Glick et al. (1995). The DF-Ammonium Sulfate or DF-ACC salts minimal medium was used to check whether the ACC deaminase produced by the isolates was part of a constitutive or inducible system as proposed by Jacobson et al. (1994). 
Am. J. Applied Sci., 8 (11): 1073-1080, 2011

Table 1: Texture and some chemical characteristic of Ultisols from Jasinga, Bogor, Indonesia

\begin{tabular}{|c|c|c|c|c|c|c|c|c|}
\hline & \multirow[b]{2}{*}{ Texture } & \multirow[b]{2}{*}{$\mathrm{pH}$} & \multirow[b]{2}{*}{ C-org. } & \multirow[b]{2}{*}{ Total N } & \multicolumn{2}{|c|}{ (Extracted $\mathrm{HCl} 25 \%)$} & \multirow[b]{2}{*}{ CEC } & \multirow[b]{2}{*}{ BS } \\
\hline & & & & & $\mathrm{P}_{2} \mathrm{O}_{5}$ & $\mathrm{~K}_{2} \mathrm{O}$ & & \\
\hline Unit & - & - & ------- & --- & ---------- & ------ & $\mathrm{cmol}_{(+)} / \mathrm{kg}$ & $\%$ \\
\hline Value & $\mathrm{SiCL}$ & 4.5 & 17 & 1.3 & 300 & 110 & 13.67 & 40 \\
\hline Status & Fine & Acidic & Low & Low & Medium & Low & Low & Low \\
\hline
\end{tabular}

$\overline{\mathrm{CEC}}=$ Cation Exchange Capacity; $\mathrm{BS}=$ Base Saturation; $\mathrm{SiCL}=$ Silty Clay Loam

The DF salts minimal medium without any supplements was included in the tests to check whether the isolates were able to fix atmospheric dinitrogen. Each isolate was grown in M26 broth culture for $24 \mathrm{~h}$ with constant shaking at $125 \mathrm{rev} \min ^{-1}$ at room temperature $\left( \pm 28^{\circ} \mathrm{C}\right)$. After overnight growth, the bacterial suspension was centrifuged at $4000 \mathrm{~g}$ for $10 \mathrm{~min}$ and cell pellets were washed with sterile distilled water. Diluted cell pellets were then spread onto each agar plate containing DF-ACC, DF-Ammonium Sulfate, or DF salts minimal media. The growth of bacterial colonies on solid media after $48 \mathrm{~h}$ incubation was used as the confirmation of the traits.

The ability of the isolates to produce IAA was checked using ferric chloride-perchloric acid reagent $\left(\mathrm{FeCl}_{3}-\mathrm{HClO}_{4}\right)$ adapted from Gordon and Weber (1951). The cell pellets of each isolate were prepared as described above and then spread onto agar plates of MS-tryptophan and incubated for $48 \mathrm{~h}$ in the dark. Subsequently bacterial colonies on agar plates were covered with $\mathrm{FeCl}_{3}-\mathrm{HClO}_{4}$ reagent. Red color around bacterial colonies was used as the confirmation of positive IAA production.

The potential antagonism of each Pseudomonas isolate against root nodule rhizobia of Bradyrhizobium japonicum Bj11 or Sinorhizobium fredii Rif5 (test bacteria) was tested by dual culture detection technique adapted from Weaver and Mickelson (1994). The ability of each potential antagonist to inhibit the growth of test bacteria was conducted in KBM agar plates inoculated with a lawn of bacterial cells from each of the eleven isolates. A $100 \mu \mathrm{L}$ of a suspension of the isolate containing approximately $10^{7}$ cells $\mathrm{mL}^{-1}$ (from $24 \mathrm{~h}$ broth culture) was spread onto the surface of KBM agar plates. A $100 \mu \mathrm{l}$ drop of a suspension of each of $B$. japonicum $\mathrm{Bj} 11$ or $S$. fredii Rif5 (from late-logarithmic growth phase) was applied to the center of agar plates. A plate without isolate inoculation was used as the control. All inoculated plates were incubated at room temperature for 5 days. The circle inhibition indicated by clear halos surrounding rhizobial colonies was considered positive for antagonism. Bacterial isolates with positive of production of ACC deaminase as well as IAA, which did not show antagonist against rhizobia, were selected for greenhouse experiments.
Growth enhancement assay: The test was conducted in green house conditions using sterile and non-sterile sieved soil in plastic pots following the protocol described by Cattelan et al. (1999). A non-sterile pot contained about $2 \mathrm{~kg}$ of sieved soil, while a sterile pot filled with a mixture of $400 \mathrm{~g}$ of sieved soil+100 $\mathrm{g}$ quart sand autoclaved twice, on 2 consecutive days (one h per day).

Plastic pots were surface disinfected with $95 \%$ alcohol. Water was added daily to each potted soil to attain a water-content equivalent to field capacity ( $0.03 \mathrm{MPa}$ ). Each experiment was performed in a randomized complete block design with 5 replications.

Bacterial inoculants for the experiments (selected from previous tests) were prepared by growing in KBM broth and subsequently transferred to M26 rich medium to produce high numbers of bacterial cells. After overnight growth by constant shaking at $125 \mathrm{rev} \mathrm{min}^{-1}$ at room temperature, bacterial cells were centrifuged at $4000 \mathrm{~g}$ for $10 \mathrm{~min}$. The cell pellets were washed with $100 \mathrm{mM}$ $\mathrm{MgSO}_{4}$ and then re-suspended in $100 \mathrm{mM} \mathrm{MgSO}$. Prior to being used for seed inoculation, the absorbance of the cell suspension was adjusted to about 0.5 at $780 \mathrm{~nm}$ using a UV Spectrophotometer, which was equal to 108-109 cells $\mathrm{mL}^{-1}$. Soybean seeds, similar in size, were surface disinfected by soaking in $70 \%$ alcohol for 1 minute and $1 \%$ sodium hypochlorite for $5 \mathrm{~min}$ and then rinsed with sterile distilled water several times. The seeds were immersed in either $100 \mathrm{mM} \mathrm{MgSO}_{4}$ which acted as a blank control (untreated), or a suspension of bacterial cells in $100 \mathrm{mM} \mathrm{MgSO}_{4}$, for $1 \mathrm{~h}$. The treated and untreated seeds were first germinated in sterile Petri dishes containing double wet filter papers. Two germinated seeds with radicle of about $1 \mathrm{~cm}$ from the same treatment were planted in each pot. After emergence, plants were thinned to one plant per pot and grown for 14 days. At harvest, the shoots were cut off and the roots were washed and their fresh weight was recorded.

Disease reduction assay. The sterile and non-sterile potted soils were prepared as described above, except the water-content of the soils was adjusted to be moister (equivalent to $-0.01 \mathrm{MPa}$ ) to allow the development of added fungal pathogens. The tests in each sterile or non-sterile soil were conducted in three separate experiments (three kinds of pathogenic fungi) following 
the protocol described by Wang et al. (2000) and Cattelan et al. (1999). Each pathogen, i.e., Fusarium oxysporum, Sclerotium rolfsii or Rhizoctonia solani, was grown in potato dextrose broth with constant shaking at room temperature and harvested after 4 and 5 days. Before inoculation to the soil, the harvested fungus was separated with mixer and suspended in sterile distilled water for $1 \mathrm{~h}$. The fungal suspension was inoculated to the potted soil and the fungal density was determined by serially plating a portion of the solution. The final counts of $F$. oxysporum, $S$ rolfsii and $R$ solani per gram of soil were about $8.1 \times 10^{4}, 1.2 \times 10^{3}$, $1 \times 10^{3}$ colony-forming units $\left(\mathrm{cfu} \mathrm{g}^{-1}\right)$, respectively. In experiments with sterile soil, besides inoculation of fungal pathogens, the sterile potted soil was also inoculated with bacterial isolates (prepared as described above) at the density $\sim 10^{7} \mathrm{cfu} \mathrm{g}^{-1}$ following the protocol described by Wang et al. (2000). Soybean seeds preparation and treatment with bacterial isolates were conducted as described above. In all experiments, the treatments included non-inoculated soil with fungal pathogen (and with bacterial inoculants) planted with untreated soybean seeds (untreated control) as well as inoculated soil with fungal pathogen planted with untreated soybean seeds.

The experiments using sterile soils were set in a randomized completely block design. Each treatment was assigned to 3 replicates where each replicate consisted of 4 pots and each pot contained 4 plants. In non-sterile soils, the experiments were conducted in a completely randomized design and each treatment was with 5 replications. Plants were grown for 14 days. Disease reduction was evaluated by the number of plants surviving and fresh weight loss. Infected plants were considered dead when they failed to recover within 14 days.

Statistical analysis all data in each experiment were analyzed by Analysis Of Variance (ANOVA) and treatment means were separated by the Duncan Multiple Range Test (DMRT) using the SAS systems for Windows 6.12.

\section{RESULTS}

Results on in vitro assay are presented on Table 2. All isolates were able to grow in DF-ACC and DFammonium sulphate minimal salts medium and use ACC or $\mathrm{NH}_{4} \mathrm{SO}_{4}$ as their sole source of $\mathrm{N}$ as an indication of their ACC deaminase activity. However, none of the isolates was able to grow in DF minimal salts medium without any addition of $\mathrm{N}$ sources indicating that the isolates did not have ability to fix atmospheric nitrogen. All isolates were able to produce IAA in minimal salt medium supplemented with tryptophan (exhibited by the red color around bacterial colonies with $\mathrm{FeCl}_{3}-\mathrm{HClO}_{4}$ reagent). With regard to rhizobial inhibition, 3 isolates (26, 53 and Crb94) inhibited at least one strain of rhizobia (Bradyrhizobium japonicum Bj11 and/or Sinorhizobium fredii Rif5); thereby limiting their use for soybean (Table 2). Based on the results, only 8 out of 11 isolates were potentially used as plant growth promoting bacteria for soybean.

Growth responses of soybean treated with 8 selected isolates are presented in Table 3. The isolates increased some aspects of plant growth in comparison to the untreated plants. The significant increase of plant fresh weight was exhibited by those treated with Pseudomonas 5, 24, 46 and Crb56 in sterile soils and with 12, 17 and Crb24 in non-sterile soils.

The ability of the isolates to reduce soybean root diseases is presented in Table 4. Plants infected with Fusarium oxysporum, Sclerotium rolfsii and Rhizoctonia solani showed yellow to yellowish leaves, brownish leaves followed by softened or rotten stems and stunted plant growth, respectively. The survival rates of untreated soybean in soils containing $F$. oxysporum, $S$. rolfsii and $R$. solani were about 85, 69 and 58\%, respectively, indicating that the destructive effects of the former pathogen were less than the later two pathogens. In sterile soils, most isolates increased the survival rates of soybean although plant fresh weight losses were variable, which could be due to different time recovery of infected plants across the treatments.

Table 2: ACC deaminase activity, IAA production, phenotypic characteristics of Pseudomonas isolates (Crb) used in the study

\begin{tabular}{|c|c|c|c|c|c|c|}
\hline \multirow[b]{2}{*}{ Isolates } & \multirow[b]{2}{*}{ DF-ACC ${ }^{\dagger}$} & \multirow[b]{2}{*}{ DF-Ammonium Sulfate } & \multirow[b]{2}{*}{ DF } & \multirow[b]{2}{*}{$\mathrm{IAA}^{\S}$} & \multicolumn{2}{|c|}{ Antagonism against } \\
\hline & & & & & Bj11 & Rif5 \\
\hline Crb5 & + & + & - & + & - & - \\
\hline Crb12 & + & + & - & + & - & - \\
\hline Crb17 & + & + & - & + & - & - \\
\hline $\mathrm{Crb} 24$ & + & + & - & + & - & - \\
\hline Crb26 & + & + & - & + & + & - \\
\hline Crb46 & + & + & - & + & - & - \\
\hline Crb47 & + & + & - & + & - & - \\
\hline Crb49 & + & + & - & + & - & - \\
\hline Crb53 & + & + & - & + & - & + \\
\hline Crb56 & + & + & - & + & - & - \\
\hline Crb94 & + & + & - & + & + & + \\
\hline
\end{tabular}

${ }^{\dagger}$ : Dworkin-Foster minimal salt medium (DF) supplemented with ACC; ${ }^{\ddagger}$ : DF supplemented with $\mathrm{NH}_{4} \mathrm{SO}_{4}$; ${ }^{\S}$ : IAA (indole-3-acetic acid) production; Antagonism against Bradyrhizobium japonicum $\mathrm{Bj} 11$ and Sinorhizobium fredii Rif5 
Am. J. Applied Sci., 8 (11): 1073-1080, 2011

Table 3: Effects of ACC deaminase-producing Pseudomonas $(\mathrm{Crb})$ on soybean growth in sterile and non-sterile soils under greenhouse conditions

\begin{tabular}{|c|c|c|c|c|}
\hline \multirow[b]{2}{*}{ Treatment } & \multicolumn{2}{|l|}{ Sterile soil } & \multicolumn{2}{|l|}{ Non-sterile soil } \\
\hline & Shoot height $(\mathrm{cm})$ & Total fresh weight $(\mathrm{g})$ & Shoot height $(\mathrm{cm})$ & Total fresh weight $(\mathrm{g})$ \\
\hline Untreated & $24.7 \mathrm{a}$ & $2.66 \mathrm{c}$ & 24.1 & $2.97 \mathrm{~cd}$ \\
\hline Crb5 & $24.8 \mathrm{a}$ & $3.47 \mathrm{a}$ & 25.4abc & $3.06 \mathrm{bcd}$ \\
\hline Crb12 & $22.8 \mathrm{~b}$ & $2.67 \mathrm{c}$ & 25.3abc & $3.38 \mathrm{a}$ \\
\hline Crb17 & $23.3 \mathrm{ab}$ & $2.68 \mathrm{c}$ & $25.3 \mathrm{abc}$ & $3.27 \mathrm{ab}$ \\
\hline Crb24 & $24.1 \mathrm{ab}$ & $2.94 b$ & $26.5 \mathrm{a}$ & $3.31 \mathrm{a}$ \\
\hline Crb46 & $24.2 \mathrm{ab}$ & $2.95 b$ & 25.0abc & $2.88 \mathrm{~d}$ \\
\hline Crb47 & $24.6 \mathrm{a}$ & $2.70 \mathrm{c}$ & $26.2 \mathrm{ab}$ & $3.03 \mathrm{~cd}$ \\
\hline Crb49 & $23.9 \mathrm{ab}$ & $2.63 \mathrm{c}$ & $24.7 \mathrm{bc}$ & $2.95 \mathrm{~d}$ \\
\hline Crb56 & $24.4 \mathrm{ab}$ & $2.94 \mathrm{~b}$ & $24.0 \mathrm{c}$ & $3.19 a b c$ \\
\hline
\end{tabular}

Numbers within a column followed by the same letter are not significantly different at $5 \%$ level by DMRT. Values are means from five replications

Table 4: Reduction in severity of diseases caused by pathogenic fungi measured by surviving plants and plant fresh weight following inoculation with ACC deaminase-producing Pseudomonas in sterile and non-sterile soils under greenhouse conditions

\begin{tabular}{|c|c|c|c|c|}
\hline \multirow[b]{2}{*}{ Treatment $^{\dagger}$} & \multicolumn{4}{|l|}{ Sterile soil } \\
\hline & $\begin{array}{l}\text { Average number of } \\
\text { surviving plants }^{\S}\end{array}$ & Survival rate $(\%)$ & $\begin{array}{l}\text { Sterile soil } \\
\text { Total fresh weight }(\mathrm{g})^{\S}\end{array}$ & $\begin{array}{l}\text { Non-sterile soil } \\
\text { Total fresh weight }(\mathrm{g})\end{array}$ \\
\hline Untreated & $4.00 \mathrm{a}$ & 100 & $9.98 \mathrm{a}$ & $2.54 \mathrm{ab}$ \\
\hline $\mathrm{Crb} 5+\mathrm{Fo}$ & $4.00 \mathrm{a}$ & 100 & $7.95 \mathrm{~cd}$ & $2.14 \mathrm{c}$ \\
\hline Crb12+Fo & $3.92 \mathrm{a}$ & 98 & $8.12 \mathrm{bcd}$ & $2.48 \mathrm{~b}$ \\
\hline Crb17+Fo & $3.92 \mathrm{a}$ & 98 & $7.59 \mathrm{de}$ & $2.53 \mathrm{ab}$ \\
\hline Crb24+Fo & $3.83 \mathrm{a}$ & 96 & $8.73 b$ & $2.71 \mathrm{a}$ \\
\hline $\mathrm{Crb} 46+\mathrm{Fo}$ & $3.75 \mathrm{ab}$ & 94 & $7.05 \mathrm{e}$ & $2.59 \mathrm{ab}$ \\
\hline Crb47+Fo & $4.00 \mathrm{a}$ & 100 & $8.45 b c$ & $2.24 \mathrm{c}$ \\
\hline Crb49+Fo & $3.83 \mathrm{a}$ & 96 & $6.28 \mathrm{f}$ & $2.29 \mathrm{c}$ \\
\hline Crb56+Fo & $3.92 \mathrm{a}$ & 98 & $7.65 \mathrm{de}$ & $2.26 \mathrm{c}$ \\
\hline Fo & $3.42 \mathrm{~b}$ & 85 & $7.52 \mathrm{de}$ & $2.25 \mathrm{c}$ \\
\hline Untreated & $4.00 \mathrm{a}$ & 100 & $8.01 \mathrm{a}$ & $2.22 \mathrm{a}$ \\
\hline $\mathrm{Crb} 5+\mathrm{Sr}$ & $3.42 \mathrm{ab}$ & 85 & $6.77 \mathrm{~b}$ & $0.42 \mathrm{f}$ \\
\hline $\mathrm{Crb} 12+\mathrm{Sr}$ & $3.75 \mathrm{ab}$ & 94 & $7.94 a$ & $0.85 \mathrm{~d}$ \\
\hline $\mathrm{Crb} 17+\mathrm{Sr}$ & $3.25 \mathrm{bc}$ & 81 & $6.51 \mathrm{~b}$ & $1.61 \mathrm{~b}$ \\
\hline $\mathrm{Crb} 24+\mathrm{Sr}$ & $3.33 b c$ & 83 & $6.58 \mathrm{~b}$ & $1.10 \mathrm{c}$ \\
\hline $\mathrm{Crb} 46+\mathrm{Sr}$ & $3.50 \mathrm{ab}$ & 88 & $5.86 \mathrm{c}$ & $1.57 \mathrm{~b}$ \\
\hline $\mathrm{Crb} 47+\mathrm{Sr}$ & $3.33 \mathrm{bc}$ & 83 & $6.88 \mathrm{~b}$ & $0.67 \mathrm{e}$ \\
\hline $\mathrm{Crb} 49+\mathrm{Sr}$ & $3.67 \mathrm{ab}$ & 92 & $6.90 \mathrm{~b}$ & $0.21 \mathrm{~g}$ \\
\hline $\mathrm{Crb} 56+\mathrm{Sr}$ & $3.50 \mathrm{ab}$ & 88 & $6.96 \mathrm{~b}$ & $0.33 \mathrm{f}$ \\
\hline $\mathrm{Sr}$ & $2.75 \mathrm{c}$ & 69 & $6.53 \mathrm{~b}$ & $0.15 \mathrm{~g}$ \\
\hline Untreated & $4.00 \mathrm{a}$ & 100 & $8.74 \mathrm{a}$ & $1.64 \mathrm{a}$ \\
\hline Crb5+Rs & $3.83 \mathrm{ab}$ & 96 & $6.82 \mathrm{~b}$ & $1.27 \mathrm{c}$ \\
\hline Crb12+Rs & $3.42 \mathrm{bc}$ & 85 & $5.15 \mathrm{a}$ & $1.14 \mathrm{c}$ \\
\hline Crb17+Rs & $3.17 \mathrm{~cd}$ & 79 & $4.77 \mathrm{~b}$ & $1.24 \mathrm{c}$ \\
\hline Crb24+Rs & $2.75 \mathrm{de}$ & 69 & $4.44 \mathrm{~b}$ & $1.24 \mathrm{c}$ \\
\hline Crb46+Rs & $3.42 \mathrm{bc}$ & 85 & $5.13 \mathrm{c}$ & $1.20 \mathrm{c}$ \\
\hline Crb47+Rs & $3.17 \mathrm{~cd}$ & 79 & $5.37 \mathrm{~b}$ & $1.17 \mathrm{c}$ \\
\hline Crb49+Rs & $3.42 \mathrm{bc}$ & 85 & $5.85 \mathrm{~b}$ & $1.45 \mathrm{~b}$ \\
\hline Crb56+Rs & $3.58 \mathrm{abc}$ & 90 & $6.16 \mathrm{~b}$ & $1.75 \mathrm{a}$ \\
\hline Rs & $2.33 \mathrm{e}$ & 58 & $4.31 \mathrm{~b}$ & $0.67 \mathrm{~d}$ \\
\hline
\end{tabular}

The significant reduction of plant weight loss was shown by plants treated with isolates Crb24 and Crb47; Crb12; and all isolates, except Crb24 in soils containing $F$. oxysporum, $S$. rolfsii and $R$. solani, respectively. On the other hand, in non-sterile soils, most plants treated with the isolates significantly reduced plant weight loss, especially in soils containing $S$. rolfsii and $R$. solani.

\section{DISCUSSION}

The importance of ACC deaminase-producing bacteria on plant growth is to reduce ethylene synthesis in plant tissues which is commonly triggered by a number of biotic and abiotic factors (Glick et al., 2007), including by increased concentration of IAA. ACC 
deaminase-producing bacteria degrade ACC (ethylene precursor) into ammonia and $\alpha$-ketobutyrate as their source of nitrogen and carbon (Jacobson et al., 1994; Glick et al., 1998); thereby ameliorating the inhibitioneffects of ethylene. In the present study, IAA produced by the isolates may promote soybean growth without being offset by increased synthesis of ACC (triggered by IAA) since their ACC deaminase activity can degrade it and prevent ethylene synthesis. However, growth promotion of soybean by the isolates was not optimum (Table 3). Low nutrient status of the soils used in the study could affect their efficacy in growth promotion. Shaharoona et al. $(2006 ; 2008)$ reported that plant growth promotion of bacteria containing ACC deaminase occurred when optimum levels of $\mathrm{N}$ fertilizer were applied. The results suggest that application of the appropriate doses of fertilizers into soil with low fertility status is required to get maximum benefit in utilizing these bacteria.

Regarding plant-pathogen interactions, it has been known that several plant pathogenic microbes have developed the ability to modulate signaling processes mediated by plant hormones as a strategy for manipulating plant growth or host physiology (Lund et al., 1998; Van Loon et al., 2006). Plants with a high level of ethylene will be in a state of ethylene-stress which inhibits plant growth. Increasing levels of ethylene exacerbates the stress and weakens plant protection against the diseases. The presence of ACC deaminase-producing bacteria residing in the root surface area reduces ethylene synthesis by hydrolyzing ACC exuded by the root and taken up by the bacteria as their source of nitrogen. Lowering ethylene levels in plants through the action of ACC deaminase-producing bacteria ameliorate the inhibitory effects of ethylene. In the present study the ability of the isolates to reduce soybean diseases was exhibited by most of the isolates although some isolates behaved differently in sterile and non-sterile soil conditions as well as the kinds of the pathogens. This variable effect suggests that the efficacy of the isolates in ameliorating disease were influenced by soil conditions and severity of pathogens, or otherwise their efficacy is specific to a certain pathogen. In line with the results, a previous report by Glick et al. (2007) concludes that the efficacy of ACC deaminase-producing bacteria on plant growth may not be clearly observed at stress-free conditions.

\section{CONCLUSION}

This study confirms the previous works on the benefits of ACC deaminase-producing bacteria on plant growth. However, the beneficial effects of Pseudomonas producing ACC deaminase as well as
IAA on soybean growth may vary depending on growth medium. The isolates increased some aspects of soybean growth and reduced disease incidence caused by Fusarium oxysporum, Sclerotium rolfsii and Rhizoctonia solani. The ability of the isolates to increase plant growth was less effective than that to reduce disease incidence. The higher the destructive effect of the pathogens, the better was the ability of the isolates to reduce the disease. Further tests are worth to evaluate whether or not the fertility status of the soil and the severity of pathogens influence the efficacy.

\section{ACKNOWLEDGMENT}

The study was supported by a grant from the Collaborative Research Project of KKP3T between the Agency for Agricultural Research and Development (AARD), Indonesian Ministry of Agriculture and Bogor Agricultural University (IPB) and Research Project from the Ministry Department of Research and Technology (RISTEK) awarded to ATW.

\section{REFERENCES}

Abeles, F.B., P.W. Morgan and M.E. Saltveit, 1992. Ethylene in Plant Biology. 2nd Edn., Academic Press, San Diego, ISBN: 0120414511, pp: 414.

Arshad, M. and W.T. Frankenberger Jr., 1991. Microbial production of plant hormones. Plant Soil, 133: 1-8. DOI: 10.1007/BF00011893

Belimov, A.A., V.I. Safranova, T.A. Sergeyeva, T.N. Egorova and V.A. Matveyeva et al., 2001. Characterization of plant growth promoting rhizobacteria isolated from polluted soils and containing 1-aminocyclopropane-1-carboxylate deaminase. Can J. Microbiol., 47: 642-652. DOI: 10.1139/w01-062

Belimov A.A., V.I Safronova and T. Mimura, 2002. Response of spring rape (Brassica napus var. oleifera L.) to inoculation with plant growth promoting rhizobacteria containing 1aminocyclopropane-1-carboxylate deaminase depends on nutrient status of the plant. Can J. Microbiol., 48: 189-199. DOI: 10.1139/w02-007

Cattelan, A.J., P.G. Hartel and J.J Fuhrmann, 1999. Screening for plant growth-promoting rhizobacteria to promote early soybean growth. Soil Sci. Soc. Am. J., 63: 1670-1680.

Dey, R., K.K. Pal, D.M. Bhatt and S.M. Chauhan, 2004. Growth promotion and yield enhancement of peanut (Arachis hypogaea L.) by application of plant growth-promoting rhizobacteria. Microbiol. Res., 159: 371-394. DOI: 10.1016/j.micres.2004.08.004 
Dworkin, M. and J.W. Foster, 1958. Experiments with some microorganisms which utilize ethane and hydrogen. J. Bacteriol., 75: 592-603. PMID: 13538930

Frankenberger Jr., W.T. and M. Poth, 1988. Ltryptophan transaminase of a bacterium isolated from the rhizosphere of Festuca octoflora (Graminae). Soil Biol. Biochem., 20: 299-304. DOI: 10.1016/0038-0717(88)90007-7

Weaver, R.W. and S.H. Mickelson, 1994. Methods of Soil Analysis: Microbiological and Biochemical Properties. 3rd Edn., Soil Science Society of America, Madison, Wis., pp: 1121.

Glick, B.R., 1995. The enhancement of plant growth by free-living bacteria. Can. J. Microbiol., 41: 109117. DOI: $10.1139 / \mathrm{m} 95-015$

Glick, B.R., D.M. Karaturovic and P.C. Newell, 1995. A novel procedure for rapid isolation of plant growth promoting pseudomonads. Can. J. Microbiol., 41: 533-536. DOI: 10.1139/m95-070

Glick, B.R., D.M. Penrose and J. Li, 1998. A model for the lowering of plant ethylene concentrations by plant growth-promoting bacteria. J. Theory Biol. 190: 63-68. DOI: 10.1006/jtbi.1997.0532

Glick, B.R., B. Todorovic, J. Czarny, Z. Cheng and J. Duan et al., 2007. Promotion of plant growth by bacterial ACC deaminase. Crit. Rev. Plant Sci., 26: 227-242. DOI: 10.1080/07352680701572966

Gordon, S.A. and R.P. Weber, 1951. Colorimetric estimation of indoleacetic acid. Plant Physiol. 26: 192-195. DOI: 10.1104/pp.26.1.192

Grichko, V.P. and B.R. Glick, 2001. Amelioration of flooding stress by ACC deaminase-containingplant growth-promoting bacteria. Plant Physiol. Biochem., 39: 11-17. DOI: 10.1016/S09819428(00)01212-2

Husen, E., A.T. Wahyudi, A. Suwanto and R. Saraswati, 2009. Soybean seedling root growth promotion by 1-aminocyclopropane-1-carboxylate deaminase-producing pseudomonads. Indonesian J. Agric. Sci., 10: 19-25.

Jacobson, C.B., J.J. Pasternak and B.R. Glick, 1994. Partial purification and characterization of 1aminocyclopropane-1-carboxylate deaminase from the plant growth promoting rhizobacterium Pseudomonas putida GR12-2. Can. J. Microbiol., 40: 1019-1022. DOI: 10.1139/m94-162

Silvia, D.M., 2005. Principles and Applications of Soil Microbiology. 2nd Edn., Pearson Prentice Hall, New Jersey, ISBN-10: 0130941174, pp: 640.
Lund, S.T., R.E. Stall and H.J. Klee, 1998. Ethylene regulates the susceptible response to pathogen infection in tomato. Plant Cell, 10: 371-382. DOI: 10.1105/tpc.10.3.371

Ma, W., F.C. Guinel and B.R. Glick, 2003. Rhizobium leguminosarum Biovar viciae 1aminocyclopropane-1-carboxylate deaminase promotes nodulation of pea plants. Applied Environ. Microbiol., 69: 4396-4402. DOI: 10.1128/AEM.69.8.4396-4402.2003

Mayak, S., T. Tirosh and B.R. Glick, 1999. Effect of Wild-Type and Mutant Plant Growth-Promoting Rhizobacteria on the Rooting of Mung Bean Cuttings. J. Plant Growth Regul., 18: 49-53. DOI: 10.1007/PL00007047

Mayak, S., T. Tirosh and B.R. Glick, 2004. Plant growthpromoting bacteria that confer resistance to water stress in tomatoes and peppers. Plant Sci., 166: 525530. DOI: 10.1016/j.plantsci.2003.10.025

Reed, M.L.E. and B.R. Glick, 2005. Growth of canola (Brassica napus) in the presence of plant growthpromoting bacteria and either copper or polycyclic aromatic hydrocarbons. Can. J. Microbiol., 51: 1061-1069. DOI: 10.1139/w05-094

Saravanakumar, D. and R. Samiyappan, 2007. ACC deaminase from Pseudomonas fluorescens mediated saline resistance in groundnut (Arachis hypogea) plants. J. Applied Microbiol., 102: 1283-1292. DOI: 10.1111/j.1365-2672.2006.03179.x

Shah, S., J. Li, B.A. Moffatt and B.R. Glick, 1998. Isolation and characterization of ACC deaminase genes from two different plant growth-promoting rhizobacteria. Can. J. Microbiol., 44: 833-843. DOI: 10.1139/w98-074

Shaharoona, B., M. Arshad, Z.A. Zahir and A. Khalid, 2006. Performance of Pseudomonas spp. containing ACC-deaminase for improving growth and yield of maize (Zea mays L.) in the presence of nitrogenous fertilizer. Soil Biol. Biochem., 38: 2971-2975. DOI: 10.1016/j.soilbio.2006.03.024

Shaharoona, B., G.M. Jamro, Z.A. Zahir, M. Arshad and K.S. Memon, 2007. Effectiveness of various Pseudomonas spp. and Burkholderia caryophylli containing ACC-deaminase for improving growth and yield of wheat (Triticum aestivum L.). J. Microbiol. Biotechnol., 17: 1300-307. PMID: 18051598 
Shaharoona, B., M. Naveed, M. Arshad and Z.A. Zahir, 2008. Fertilizer-dependent efficiency of Pseudomonads for improving growth, yield and nutrient use efficiency of wheat (Triticum aestivum L.). Applied Microbiol. Biotechnol., 79: 147-155. DOI: 10.1007/s00253-008-1419-0

Van Loon, L.C., B.P.J. Geraats and H.J.M. Linthorst, 2006. Ethylene as a modulator of disease resistance in plants. Trend Plant Sci. 11: 184-191. DOI: 10.1016/j.tplants.2006.02.005
Wang, C., E. Knill, B.R. Glick and G. Defago, 2000. Effect of transferring 1-aminocyclopropane-1carboxylic acid (ACC) deaminase genes into Pseudomonas fluorescens strain CHA0 and its gacA derivative CHA96 on their growth-promoting and disease-suppressive capacities. Can. J. Microbiol., 46: 898-907. DOI: 10.1139/w00-071 